\title{
Thematic Learning: Are Primary School Teachers Ready to Integrate Mathematical Connections in Learning in Schools?
}

\author{
Mohammad Archi Maulyda \\ Primary Teacher Education Study \\ Program \\ University of Mataram \\ Mataram, Indonesia \\ archimaulyda@unram.ac.id
}

\author{
Awal Nur Kholifatur Rosyidah \\ Primary Teacher Education Study \\ Program \\ University of Mataram \\ Mataram, Indonesia \\ awal_rosyidah@unram.ac.id
}

\author{
Vivi Rachmatul Hidayati* \\ Primary Teacher Education Study \\ Program \\ University of Mataram \\ Mataram, Indonesia \\ vivirachma@unram.ac.id
}

\author{
Iva Nurmawanti \\ Primary Teacher Education Study Program \\ University of Mataram \\ Mataram, Indonesia \\ ivanurmawanti@unram.ac.id
}

\author{
U Umar \\ Primary Teacher Education Study Program \\ University of Mataram \\ Mataram, Indonesia \\ umarelmubaraq90@unram.ac.id
}

\begin{abstract}
Mathematical connection is an important aspect of learning mathematics. Especially for elementary school teachers, where since the 2013 curriculum was launched lowgrade elementary school teachers (Class I, II, and III) are obliged to implement a thematic learning system. In thematic learning, many mathematical connection processes occur. Therefore, the researcher aims to explore teachers' understanding and experiences in integrating students' mathematical connection skills into classroom learning. The research method used is a qualitative-descriptive method to describe the learning phenomenon based on mathematical connections. The research subjects were 24 elementary school teachers in cluster IV Mataram City with the criteria; (1) The length of teaching is more than seven years (since the 2013 curriculum was issued); (2) Teachers who teach in Low class (Class I, II, \& III); and (3) The teacher is willing to be a subject in the research. The research procedure carried out was the provision of an online google form survey link. Then it was done to each subject via WhatsApp call to strengthen the survey answers for each subject. Data analysis was conducted descriptively using mathematical connection indicators in NCTM. The results showed that the implementation of learning based on mathematical connections was not optimal, where only indicators D1 and D2 were met. The D3 indicator is not fulfilled, which means that the teacher never makes student worksheets (LKS) that contains or connects mathematical concepts with condep outside mathematics.
\end{abstract}

Keywords - connections, elementary school, mathematics, thematic

\section{INTRODUCTION}

Thematic learning is a new paradigm in the process of transferring knowledge at the elementary school level (SD). Thematic learning was launched in the 2013 curriculum [1]. Thematic learning for students in grades 1-3 SD (low grade) is essentially based on understanding self-regulation [2]. In a self-regulatory system, every thought process carried out by humans comes from various kinds of concepts and scientific disciplines. Based on this understanding, Jacob with his interdisciplinary learning concept and Fogarty with the concept of integrated learning gave birth to a thematic learning paradigm [3]. Even though it is a long learning paradigm, the application of this thematic learning system was only adopted in Indonesia's learning system when the 2013 curriculum was issued.

The implementation of thematic learning systems for low-grade elementary schools is in fact quite difficult for school teachers. According to research results [4] teachers in schools are still not used to providing various kinds of concepts in one lesson. This happens because the currently teaching teachers do not have the same learning experience as thematic learning. So that the habit of the learning process, which usually only dwells on the same scientific field is difficult to change [5]. According to research results [4], the result is the implementation of thematic learning in low grade elementary schools is still not optimal. There are still many teachers who teach in the old way, and only carry out the implementation of thematic learning in the administrative realm.

Especially if this thematic learning system involves mathematics subjects. Not all subjects can be related to mathematics. The abstract nature of mathematics while elementary school students are still at a concrete stage, making teachers have difficulty connecting mathematics with other subjects. Teachers will be limited by several concepts that exist in other subjects, but not in accordance with the level of primary school education. This is the teacher's biggest difficulty in connecting mathematics in a thematic learning system.

More specifically in learning mathematics, there is a basic ability known as a mathematical connection. Mathematical connection is one of the 5 aspects of mathematics formulated by the National Council of Teachers of Mathematics (NCTM) [6]. In the indicators of 
mathematical connections, very thick elements of thematic learning are reflected. Mathematical connection is an attempt to build a connection between mathematical concepts and concepts in other scientific fields. This is the basic key in thematic learning, which is an attempt to teach one big theme by connecting different scientific concepts. [7] - [8]. As a preliminary study, researchers tried to dig up information related to the implementation of mathematical connectionbased learning in schools by providing online surveys via a google form. Respondents who were given the survey link were 24 elementary school teachers in Cluster IV Mataram City. Following are the results of the survey conducted:

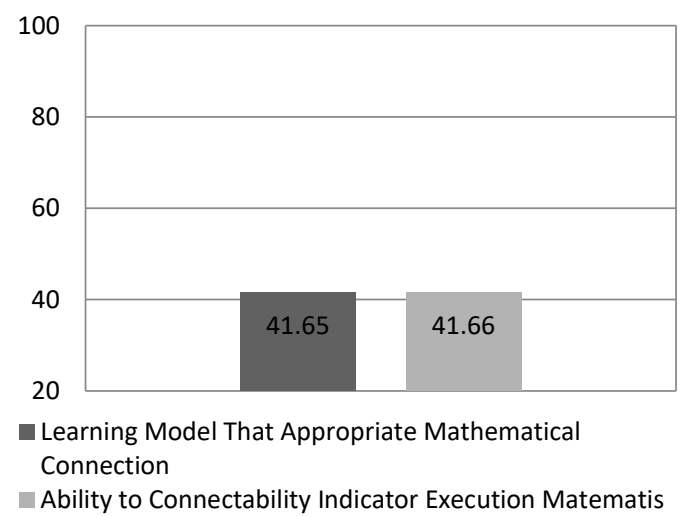

Fig. 1. Learning Implementation based on Mathematical Connection in Schools

In Fig. 1, it can be seen that the implementation of mathematics learning based on mathematical connections in schools is still low. In the blue histogram, it can be seen that not many school teachers have used a learning model that is in accordance with the mathematical connection ability, namely Contextual Learning. According to [9] the contextual learning model is the right model to invite students to learn to draw the relationship between what is being learned and what is faced in real conditions. In line with that, [10] explained that contextual learning is proven to be able to make students more sensitive to examples of personal experiences that are in accordance with the mathematical concepts being learned. In learning with the CTL model, students are required to relate a concept being learned with other concepts or with real-life conditions. [11]. This is of course very much in line with the thematic learning system that is currently applied at the basic education level. Meanwhile, the blue histogram shows that the implementation of the mathematical connection indicator in learning in schools is still low.

Responding to the results of this preliminary study, the researcher aims to explore information about teachers 'understanding and experiences in integrating students' mathematical connection skills into classroom learning. Seeing the relationship between aspects of mathematical connections with thematic learning in schools, researchers will dig up information related to the implementation of mathematical connections in schools. It is hoped that the results of this study can provide an overview of the readiness of elementary school teachers in the thematic learning process in schools.

\section{METHODS}

To achieve the research objectives, namely to describe the understanding and experience of teachers in integrating mathematical connection skills in learning, researchers used a qualitative-descriptive research approach. According to [12] Qualitative research can provide a real, factual picture of a phenomenon. The research subjects were 24 elementary school teachers in Cluster IV Mataram City. The selection of research subjects was based on the following criteria: (1) The length of teaching was more than 7 years (since the 2013 curriculum was issued); (2) Teachers who teach in Low class (Class I, II, \& III); and (3) The teacher is willing to be a subject in the research. The instrument used in this research is a google form survey which will be distributed to research subjects online. The second instrument is a guideline for interviews conducted via WhatsApp to research subjects. The purpose of conducting interviews is to strengthen the survey answers given online previously.

The use of this platform takes into account the COVID19 Health procedures, all research procedures are carried out online. The first step is that the researcher asks the research subject to fill out a survey given via the google form link. Subjects who have filled out the survey are then interviewed via WhatsApp call related to the survey results that have been filled in. Furthermore, the results of the survey and interview were analyzed descriptively using mathematical connection indicators as follows:

TABLE I. MATHEMATICAL CONNECTION INDICATORS

\begin{tabular}{|c|c|c|c|}
\hline Aspect & Indicator & Description Indicator & Code \\
\hline \multirow[t]{3}{*}{$\begin{array}{l}\text { Mathematical } \\
\text { Connection }\end{array}$} & $\begin{array}{l}\text { Unifying } \\
\text { Themes }\end{array}$ & $\begin{array}{l}\text { - The teacher conveys the } \\
\text { objectives and benefits } \\
\text { of learning the concept } \\
\text { of learning with other } \\
\text { materials } \\
\text { - The teacher gives } \\
\text { examples of problems } \\
\text { related to everyday life }\end{array}$ & DD1 \\
\hline & $\begin{array}{l}\text { Mathematical } \\
\text { Processes }\end{array}$ & $\begin{array}{l}\text { - Teachers assist students } \\
\text { in solving mathematical } \\
\text { problems } \\
\text { - Teachers can insert other } \\
\text { materials in the } \\
\text { mathematics learning } \\
\text { process }\end{array}$ & DD2 \\
\hline & $\begin{array}{l}\text { Mathematical } \\
\text { Connectors }\end{array}$ & $\begin{array}{l}\text { - The teacher once gave } \\
\text { student worksheets } \\
\text { (LKS) that contained } \\
\text { more than } 1 \text { concept } \\
\text { (other than mathematics) } \\
\text { - The teacher invites } \\
\text { students to link learning } \\
\text { conclusions with } \\
\text { students' daily lives }\end{array}$ & DD3 \\
\hline
\end{tabular}

\section{RESULTS AND DISCUSSION}

In an integrated world, a connection is an important thing to discuss. The connection that is born in the joints of human life certainly aims to facilitate work and optimize the results of human work [13]. Likewise, in education, the connection 
is a keyword and ability that a child must have [14]. One manifestation of this statement is the birth of a thematicbased basic education system. Thematic education is a learning process that integrates various subjects into one big theme [15]. This kind of learning system, especially for students at the basic education level, is intended to train these students to have the ability to connect from an early age [16].

The ability to connect is also one of the five basic math skills proclaimed by NCTM [6]. According [17], mathematical connection ability is students' ability to draw relationships between topics in mathematics or mathematics topics with other learning topics. The ability of mathematical connections and thematic learning systems at the primary school level have a close relationship. But in fact, there are still many research subjects who do not understand the ability of mathematical connections. Following are the results of the survey conducted regarding the teacher's understanding of mathematical connections:

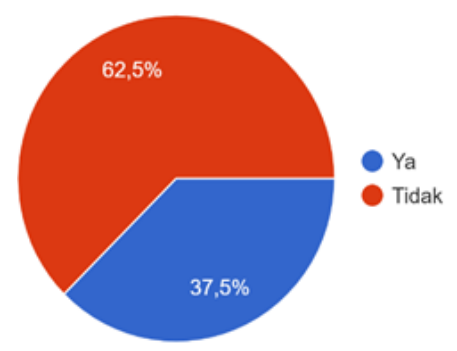

Fig. 2. Percentage of Subjects who have heard the term mathematical connection

Based on Fig. 2, it can be seen that $62.5 \%$ (15 subjects) have never heard of the term mathematical connection, while $37.5 \%$ (9 subjects) have heard of it. This shows that most of the subjects who are teachers at the elementary school level have never heard of a mathematical connection. Even though in thematic learning, the elements of mathematical connections have been done by the subject. To clarify the results of the research, the implementation of the mathematical connection indicators will be described as follows:

\section{Unifying Themes (D1)}

The initial stage in implementing a mathematical connection is the activity of unifying themes or bringing together lesson topics in learning. According to [18] Including various topics in learning will lead students to an interesting and not boring learning experience. Especially for children at the basic education level, psychologically [19] explained that the cognitive processes that occur in children tend to overlap each other and are not yet organized. Focusing on the field of mathematics, practicing mathematical connections in children will help students organize cognitive processes that occur before. According to [20] The activity of providing examples outside the topic of learning mathematics will train students' mathematical connection skills. The following are the results of the subject's answers related to providing examples on topics outside of mathematics:

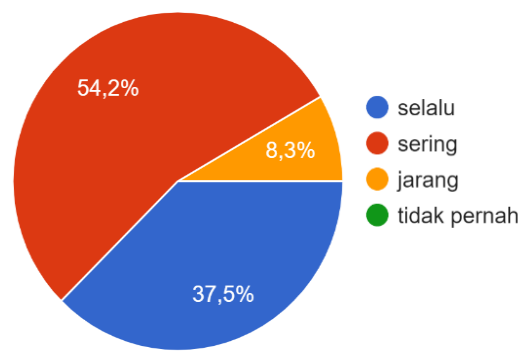

Fig. 3. Indicator Implementation Unifying Themes

Based on the image above, it can be seen that most subjects have provided examples outside of mathematical topics. This is suspected to be due to the thematic learning system launched at the primary school education level, so that the subject always integrates examples from various subject topics. Tabulatively, 54.2\% (13 subjects) often carry out this learning activity, while $37.5 \%$ (9 subjects) always do this activity, the remaining $8.4 \%$ (2 subjects) rarely give examples outside of mathematics topics. Reflecting on the results of this tabulation, it can be said that the D1 indicator has been met. According to [21] teachers tend to prefer to teach mathematics with the example and counter example method. In line with it, according to [14] examples and cons examples can help students understand mathematical concepts that are very abstract in nature.

\section{Mathematical Processes (D2)}

The next stage in the mathematical connection indicator is to carry out a mathematical process. According to [22] mathematical processes will always require holistic connections between concepts. The sequence of concepts in mathematics is very clear, because mathematics always departs from one definition or theorem [17]. Because it departs from something very basic, the mathematical concepts always move sequentially and systematically. Based on the results of interviews with subjects related to student difficulties in connecting mathematical concepts, they are as follows:

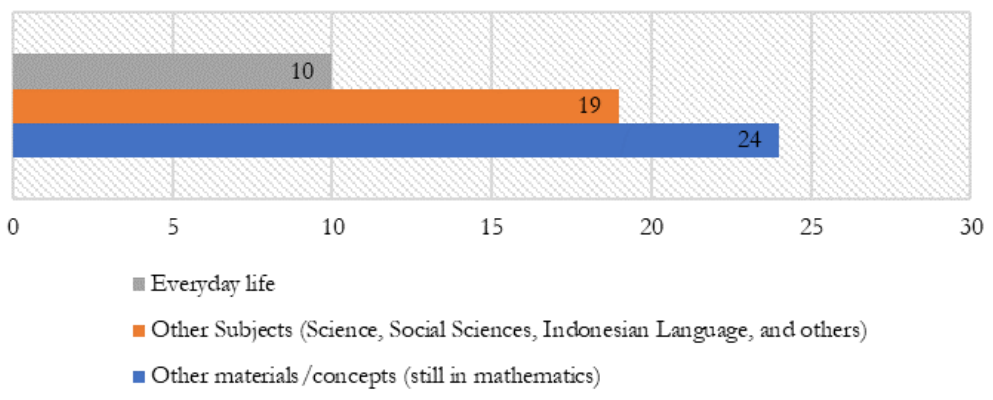

Fig. 4. Students' difficulties in the mathematical connection process 
Based on Fig. 4, it can be seen that the most common difficulty faced by students is connecting mathematical concepts with other mathematical materials/concepts. The number of subjects who chose this was 24 subjects, meaning that all subjects had encountered students who had difficulty connecting mathematical concepts with other mathematical concepts. According to [23] This difficulty is suspected because the mathematical concepts taught are not systematic and sequential. Meanwhile, 19 subjects found it difficult to connect mathematical concepts to the concepts of other subjects. This is not in line with the research results [24] that thematic-based learning can help students understand a concept broadly and deeply. Even though there are still many difficulties encountered by students, the D2 indicator has been fulfilled because the subject has carried out a mathematical process in learning.

\section{Mathematical Connectors (D3)}

The last indicator in the implementation of the mathematical connection process is to connect the mathematical concept with other learning concepts. According to [25] Mathematics is an abstract and very basic concept. For example, in the concept of physics, the elements of mathematics that appear are very thick. Even according to [26] Mathematical concepts can be included in all other scientific fields. Because basically, the concept of Mathematics will always appear in other scientific fields. One form of mathematical connection that can be trained to students is the provision of worksheets containing other concepts. Following are the results of tabulation of survey data conducted on subjects related to giving student worksheets:

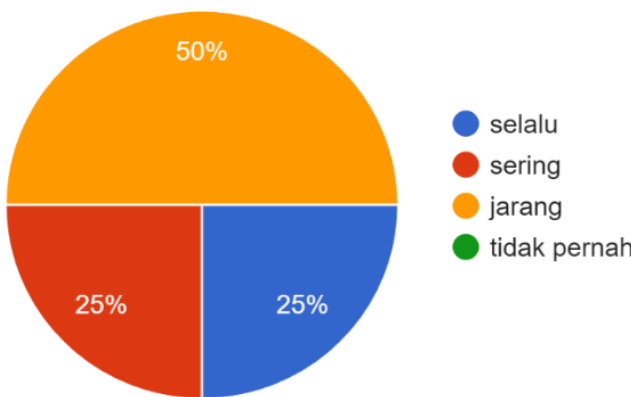

Fig. 5. Giving Student Worksheets (LKS) containing 2 or more concepts

As seen in the picture above, the subject still rarely gives worksheets containing 2 or more concepts. This shows that the D3 indicator is not fulfilled. So, it can be concluded that the thematic learning process has not been implemented. According to [27] Thematic learning among elementary school teachers is currently still very low in implementation. In addition to this, because this system is classified as a new education system, it is also because the teachers do not yet have the skills to combine lesson concepts into one learning theme at the same time [28].

\section{CONCLUSION}

Based on the results of the research conducted, it can be concluded that: (1) The readiness of elementary school teachers in Cluster IV Mataram City in carrying out thematic learning is still lacking, this can be seen from the unfulfilled D3 indicator. Teachers still rarely provide multidisciplinary
Student Worksheets (LKS). (2) The mathematics learning that has been carried out so far has not fulfilled the elements of a mathematical connection. Teachers are not used to making questions or supporting learning tools that contain other concepts outside of mathematical concepts. (3) The mathematical connection that is most difficult for the teacher to build is connecting one mathematical concept to another. This shows that the mathematical connection ability of teachers is still low. Based on the research findings data, the researcher formulates the following recommendations: (1) Teachers must familiarize themselves with making worksheets that contain more than 1 subject area according to the thematic learning paradigm. (2) An in-depth study was conducted on the mathematical connection ability of elementary school teachers. This information will assist teachers in designing mathematical connection-based learning.

\section{ACKNOWLEDGMENT}

Thank you for the PNBP funding support from the DIPA BLU University of Mataram funds for the 2020 fiscal year, with the contract/agreement number: 2572 / UN18.L1 / PP / 2020.

\section{REFERENCES}

[1] K. E. N. Nahak, I. N. S. Degeng, and U. Widiati, "Pembelajaran Tematik di Sekolah Dasar," J. PendidikanTeori, Penelitian, dan Pengemb., vol. 4, no. 2, pp. 23-34, 2019.

[2] D. D. Chrisyarani and A. D. Yasa, "Validasi modul pembelajaran: Materi dan desain tematik berbasis PPK," Prem. Educ. J. Pendidik. Dasar dan Pembelajaran, vol. 8, no. 2, pp. 206-2015, Dec. 2018.

[3] S. Ratnaningsih and G. Nastiti, "Upaya Meningkatan Motivasi Belajar Siswa dengan Menggunakan Media Gambar Pada Pembelajaran Tematik di Sekolah Dasar," Al Ibtida J. Pendidik. Guru MI, vol. 5, no. 2, p. 275, Oct. 2018.

[4] N. Indrianto and D. N. Fatmawati, "Teacher Skills in Classroom Management in Thematic Learning in Elementary Schools/Keterampilan Guru dalam Pengelolaan Kelas pada Pembelajaran Tematik di Madrasah Ibtidaiyah," J. AL-MUDARRIS, vol. 3, no. 1, pp. 15-34, Apr. 2020.

[5] L. Usriyah and M. S. Prayogo, "Problematika Implementasi Pembelajaran Tematik Integratif di Lembaga Pendidikan Dasar Islam: Studi Kasus di Madrasah Ibtidaiyah Negeri (MIN) Garahan Jember Jawa Timur," TADRIS J. Pendidik. Islam, vol. 13, no. 2, pp. 34-43, Dec. 2018.

[6] S. Hekimoglu and M. Sloan, "A Compendium of Views on the NCTM Standards," Math. Educ., vol. 15, no. 1, pp. 35-43, 2015.

[7] T. A. Brocato et al., "Understanding the Connection between Nanoparticle Uptake and Cancer Treatment Efficacy using Mathematical Modeling," Sci. Rep., vol. 8, no. 1, pp. 75-89, Dec. 2018 .

[8] A. Urbaś, "Mathematical Description of a Flexible Connection of Links and its Applications in Modeling the Joints of Spatial Linkage Mechanisms," Lat. Am. J. Solids Struct., vol. 13, no. 15, pp. 28962921, Dec. 2016.

[9] C. J. Young, S. C. Levine, and K. S. Mix, "The Connection Between Spatial and Mathematical Ability Across Development," Front. Psychol., vol. 9, no. 3, pp. 138-147, Jun. 2018.

[10] M. Mogege, "Mathematical concepts from community elders: exploring the connection between ethnomathematical contexts and classroom practices,” ETD - Educ. Temática Digit., vol. 19, no. 3, pp. 667-678, Jul. 2017.

[11] G. F. Khairunnisa, M. A. Maulyda, A. M. Annizar, and L. Hijriani, "Mathematics Communication: Translation of Elementary Students' Idea,” Numer. J. Mat. dan Pendidik. Mat., vol. 4, no. 2, pp. 77-86, 2020 . 
[12] J. W. Cresswell, Educational Research: Planning, Conducting, and Evaluating Quantitative and Qualitative Research 4th Edition. Boston: Pearson, 2012.

[13] D. Rohendi and J. Dulpaja, "Connected Mathematics Project (CMP) Model Based on Presentation Media to the Mathematical Connection Ability of Junior High School Student," J. Educ. Pract., vol. 4, no. 4, pp. 17-22, 2013.

[14] M. K. Mhlolo, H. Venkat, and M. Schäfer, "The nature and quality of the mathematical connections teachers make," Pythagoras, vol. 33, no. 1, pp. 12-24, May 2012.

[15] M. Mulyadin, "Implementasi kebijakan pembelajaran tematik terpadu Kurikulum 2013 di SDN Kauman 1 Malang dan SD Muhammadiyah 1 Malang," J. Edutama, vol. 5, no. 3, pp. 124-135, 2016.

[16] S. N. Nafia Wafiqni, "Model Pembelajaran Tematik," Al Bidayah J. Pendidik. Dasar Islam, vol. 2, no. 3, pp. 76-87, 2018.

[17] S. Haji, M. I. Abdullah, S. Maizora, and Y. Yumiati, "Developing students' ability of mathematical connection through using outdoor mathematics learning," Infin. J., vol. 6, no. 1, p. 11, Jan. 2017.

[18] D. Siregar and E. Surya, "Analysis of Students' Junior High School Mathematical Connection Ability,” Int. J. Sci. Basic Appl. Res., vol. 33, no. 2, pp. 309-320, 2017.

[19] F. Safi and S. Desai, "Promoting Mathematical Connections Using Three-Dimensional Manipulatives," NCTM, vol. 22, no. 8, pp. 101$111,2017$.

[20] H. Hemdriana, A. Slamet, and U. Sumarmo, "Mathematical connection ability and self-confidence (An experiment on Junior High School students through Contextual Teaching and learning with
Mathematical Manipulative)," Int. J. Educ., vol. 8, no. 1, pp. 1-11, 2014.

[21] Rusmini and E. Surya, "The Effect of Contextual Learning Approach to Mathematical Connection Ability and Student SelfConfidence Grade Viii Smp Negeri 8 Medan,” Int. J. Sci. Basic Appl. Res., vol. 35, no. 2, pp. 249-262, 2017.

[22] V. R. Hidayati, M. A. Maulyda, G. Gunawan, A. N. Rahmatih, and M. Erfan, "System of Linear Equation Problem Solving: DescriptiveStudy about Students' Mathematical Connection Ability," J. Phys. Conf. Ser., vol. 1594, p. 012042, 2020.

[23] K. Komatsu, "A framework for proofs and refutations in school mathematics: Increasing content by deductive guessing," Educ. Stud. Math., 2016.

[24] S. J. Rushton, "Teaching and learning mathematics through error analysis," Fields Math. Educ. J., vol. 3, no. 1, pp. 14-26, Dec. 2018.

[25] R. Berry and K. Thunder, "Mathematics Education at Teachers College," J. Math. Educ. Teach. Coll., vol. 3, no. 1, pp. 43-55, 2012.

[26] W. Murtafiah, C. Sa'dijah, T. D. Chandra, S. Susiswo, and A. R. As'ari, "Exploring the explanation of pre-service teacher in mathematics teaching practice," J. Math. Educ., vol. 9, no. 2, pp. 259270, Jun. 2018.

[27] H. Karli, "Penerapan Pembelajaran Tematik SD Di Indonesia," EduHumaniora," J. Pendidik. Dasar Kampus Cibiru, vol. 12, no. 3, pp. 45-78, 2016.

[28] Trianto, Desain Pengembangan Pembelajaran Tematik: Bagi Anak Usia Dini TK/RA \& Anak Usia Dini Kelas Awal SD/MI, 2nd ed. Malang: Djambatan, 2013. 